\title{
The Holy Spirit in the Teaching of N.F.S. Grundtvig
}

\author{
By A.M. Allchin
}

The aim of this article is exploratory rather than definitive. It is based on a lecture given in the Faculty of Theology in the University of Copenhagen in April 1998, in connection with the fiftieth anniversary of the Danish branch of the Fellowship of St Alban and St Sergius. While it reflects something of the Fellowship's concern to encourage interaction and exchange between Western and Eastern Christendom, its principle focus is on Grundtvig's understanding of the relation of the Holy Spirit to bodiliness, a subject which is explored from a number of different points of view.

\section{$I$}

The subject of the Holy Spirit in the teaching of N.F.S. Grundtvig is of course a very large one. I want to start from what may seem a strange place, from Martensen's report of his conversations with Grundtvig to be found in his memoirs. I have been struck by this passage, first because it shows the two men at a moment when they were still on friendly terms with one another and secondly because it shows a point on which Martensen felt complete and wholehearted agreement with Grundtvig. I think we often understand people better when we agree with them than when we disagree with them; and Martensen was after all one of the finest theological minds of his time in Denmark.

The matter on which Martensen found himself in full agreement with Grundtvig was that of bodiliness.

»Although the spirit was for him the first, indeed the only truly real, yet he could not think of the spirit without bodiliness, and the spirit from which nature and the bodily was excluded, was for him an abstract spirit, the spirit of the rationalists with which he would have nothing to do. Thus he had in his viewpoint a higher, spiritual realism, which is also found in Lutheranism, particularly in the teaching about the sacraments. 
Here I was in complete agreement and thereby also in the great importance he gave to image language, which for him had a greater truth and reality than abstract concepts and whose highest form he found partly in holy scripture in the utterances of the prophets and the sayings of Christ, partly in the myths and symbolic language of the North. There was to be no playing with image language, and he often said that true poets were serious in their use of such language and that through it they expressed the truth in their view of life. ${ }^{1}$

There are four points in this passage which I would like to remark on. First there is the question of bodiliness and its inherent link with the spirit. Second there is the question of the relationship between the human spirit and the divine Spirit, which is not explicitly mentioned but is certainly presupposed in the conversation. Third there is the way in which this relationship between spirit and body illuminates the theology of the sacraments. Fourth there is the way in which it also illuminates the use of image language in the Old and New Testament, in the worship of the Church, and more generally in the language of poets and prophets of all nations, and especially those of the North.

II

From this starting point I want to explore Grundtvig's discussion of these matters from different periods in his life. First I want to go to 1841 and to his work Kirkelige Oplysninger isar for Lutherske Christne. The passage with which I am concerned begins with the thought of the Church and the place of the Holy Spirit in the Church, it then moves to a more general consideration of the role of the Holy Spirit in human society as a whole. Grundtvig declares that the proclamation of the Gospel presupposes »a living relationship between Christ and his faithful disciples.... and such a living relationship can only come into being when his Spirit, as a divine, self-authenticating power of life, dwells in and works through the Church." It was Grundtvig's belief that lack of this understanding of the Holy Spirit »as a divine person, Christ's representative on earth, his Church's power of life, its pastor, teacher and guide, « was one of the principle 
causes of the nineteenth century's »abstract conception of Spirit and spiritual reality and its material conception of freedom and personality, which, where they are dominant, make any living relationship between heaven and earth, God and man, and between Christ and us, evidently impossible ${ }^{2}{ }^{2}$

In this particular work, which is written in dialogue with the Tractarians and in particular with Newman, Grundtvig is concerned about the way in which the work of the Spirit creates the unity of the Church across space and still more across time. He maintains that the Lord and the Spirit are not bound by space and time.

»They can and will work just as powerfully, livingly, and joyfully in all believing generations, and under all the quarters of heaven, so that in this connection there can be no more separation between the first and the nineteenth century, than there was between Jews and Greeks, Scythians and Barbarians; all difference falls away in exactly the same degree as the Spirit of the Lord works with power bringing all together into communion with the Lord who is the same yesterday and today and forever. $\aleph^{3}$

In this passage we see how the Spirit is central and vital to the life of the Church in Grundtvig's understanding of things, and how it is the power of the Spirit which makes us contemporary with Christ. This, he maintains however, is a truth not generally recognised; and from this lack of recognition there are disastrous consequences, not only for the life of the Church, but also for the life of society in general. Grundtvig suggests that this deficiency in theology has had consequences far beyond the strictly theological realm; he also suggests that a consequent deficiency in philosophy and anthropology in general has had disastrous consequences for the life of the Church. There has been, as so often in his thought, an interaction between sacred and secular, between ecclesiastical and national. The work of the Spirit is vital, not only for the life of the Church, for redeemed humanity, but for the life of society, for the life of humanity as a whole, without it we are left with an abstract concept of spirit and spiritual reality and a material concept of freedom and personality. 
We turn back to a very different period of Grundtvig's life, when his circumstances were very different, and look at two of the essays in Danne-Virke dating from 1817.

At this time Grundtvig had no public office in the Church. He lived as a freelance writer and scholar, studying, writing and translating. He was particularly involved in early medieval texts from Danish and Scandinavian history, immersing himself in the distant past of the people to whom he belonged. He was also involved in the translation of Beowulf. He was thus in touch with the great early Anglo-Saxon epic poem, which he saw - but at that time almost noone else did - to be profoundly if often implicitly Christian in its basic structures and intentions. In this very year he published a poem Ragna-Roke in which he celebrated the Anglo-Saxon seer and poet Caedmon as a true successor to King David, a model for future Christian bards in the North.

$\mathrm{He}$ is therefore, in this essay, discussing our question of the relation of spirit and body in a very different context; in relation to the nature of human knowledge. He is seeing the question in the context of philosophical idealism on one side and philosophical materialism on the other. He is also seeing the question in the context of a romantic view of poetry which sees the inspired poet as himself the creator of his material, and a classical view of poetry which sees the poet as the careful craftsman who shapes and adorns material which he has inherited from the tradition to which he belongs. In both cases Grundtvig rejects the oppositions described and takes a middle way. The poet is both apprehending and active, to use the terms of Anders Pontoppidan Thyssen, the poet both receives and innovates. We may remark that this is precisely what he is doing in his creative appropriation of the Anglo-Saxon heritage. And, as we shall see, this is not for him something true of poets alone. In a different way it is true of all those who take an active part in the life of the society they belong to and the Church of which they are a part. And this, as we shall discover, is because the human situation is at once necessarily bodily and spiritual. 
As bodily creatures located in space human beings are destined to play their part in the natural world and as bodily creatures located in time they are destined to play their part in the historical community to which they belong. But in both cases the element of spirit which is inherent in the human condition links them to a higher and eternal reality, which enables them to share in some measure in the creative power of the eternal realm.

So in his discussion of the nature of human knowledge Grundtvig affirms that all knowledge rests on sensory experience. "Bodily and spiritual are in no way in opposition to one another, in the way in which falsehood and truth are. They in no way abolish or deny one another, but are linked in a friendly interaction, which presupposes a common reality and a common origin.«

The human condition "consists of something bodily and something spiritual which together make up a unity, fused together in a selfconsciousness which constitutes neither bodily nor spiritual existence alone, but human existence, the reasonable personhood which is a conjunction of both «. This inward conjunction of spirit and body creates »an unshakeable wall against all idealism; against all denial of the rational reality of our bodily nature. $\ll^{4}$

In other words Grundtvig is asserting that spirit is never disembodied; that human flesh is never without reason or spirit. Humankind is always a conjunction of body and spirit and in this conjunction human beings become living souls. Furthermore, we know through the conjunction of body and spirit, and this necessarily means that we know and express ourselves in and through bodily images. Bodily images rather than abstract concepts are the primary way in which human beings express their understanding of life.

In theological terms, Grundtvig sees these matters in the light of the verse in Genesis, „God breathed the breath of life into man's nostrils, and man became a living soul.$^{5}$ In his understanding the breath of life is the gift of the Holy Spirit and it brings spirit and body together into one. Thus human spirit is understood as given by, and energised by, God's Spirit. So man lives in the closest dependence on and in the closest relation to God.

Human self-awareness develops as man's awareness of his relationship with God the Holy Spirit develops. Humankind comes to see everything truly in the light of the Spirit, the light of eternal truth. »Man sees himself as created in God's image, and he sees the uni- 
verse, as God's handiwork.« In other words man sees and knows himself as a unity of body and spirit, and sees in and through bodily images. It is the nature of poetry to reveal the universe in this light. »Image language has greater truth and reality than abstract concepts, « as Martensen remarks.

Man grows in his consciousness »of this double relationship, this relationship to the world which his body expresses, this relationship to the divine to which his spirit bears witness. ${ }^{6}{ }^{6}$ It is interesting to see how carefully Grundtvig differentiates the relationship between the body and the world around which is a simple relationship of solidarity which the body can fully express, and the relationship between the human spirit and the divine to which the human spirit bears witness, thereby recognising the distance which exists between the Creator and the creature. Grundtvig goes on »the one relationship is kingly, the other relationship is that of a servant, so that both together united constitute a representative or ambassadorial relationship. To work out this union, to embrace this double relationship with thanksgiving and afterwards to hold it fast in love, this is the human calling. ${ }^{7}$

In this way the human person is seen both as a microcosm and as a mediator. Linked with the world around by his bodily nature, linked by his created spirit with the Creator Spirit who breathes his life into him. We are very close here, not so much in language as in ideas, to some of the basic themes of much patristic theology. So we are not altogether surprised to discover Grundtvig himself using Greek terms to express this situation. Humanity he tells us is to be understood cosmologically in relation to creation and theologically in relation to God. ${ }^{8}$

We have been looking at Grundtvig as the essay writer. Now we come to see him as the preacher, and to discover his understanding of how the Bible uses these terms flesh and Spirit, both in the Old Testament and in the New Testament and in particular in St Paul.

The sermon from which I am quoting dates from October 1825 (Trinity 15). It was preached in the very week in which Clausen was initiating the court case against Grundtvig. Grundtvig is now very 
much in the midst of affairs. His mature point of view on the Church, his kirkelige anskuelse has developed rapidly and become much more articulate. But his view on the relation of body and spirit as expressed in this sermon is, in its basic outline, the same as it had been some ten years earlier. Now, however, it is explained in biblical terminology.

»We soon learn that the Scripture uses the word flesh for everything that is earthly and spirit for everything that is heavenly in us, and now it follows of itself that flesh very often means something evil, because our flesh has become sinful, but yet it can also mean simply our earthly nature in its necessary created limitation and weakness. So when it says »the Word was made flesh and dwelt among us «, there flesh evidently means only our earthly nature, for the Son was made like us in all things except in sin, and as the Lord says »the spirit is willing but the flesh is weak «, and when the apostle speaks of the weakness of the flesh, he refers only to what in the course of time is inseparable from our earthly condition. We can all understand that sin was not a necessary consequence of this weakness, for God saw all that he had made and behold it was very good, and the Spirit witnesses to this when he says that the Son came in the likeness of sinful flesh and condemned sin in the flesh, and thus showed that there could also be flesh which was without sin, and that it was thus that flesh was created, for just as Jesus became man without an earthly father, only of an earthly mother, through the power of the Holy Spirit, so also Adam became man, for the earth was his mother, and his father was God, who breathed the Spirit of life into his nostrils, so that he became a living being.»

We see again the vital importance of this verse.

"Thus the flesh in humankind is originally God's creation, weak in itself, but in conjunction with the Spirit of God capable of obeying God and doing his will, and by degrees of becoming spiritual, being changed and transfigured into his image, in whom it was created. ...Flesh and spirit are therefore in the beginning in no way set in opposition to one another, so 
that they should come into conflict, for in Jesus they were not in conflict. ${ }^{9}$

We see in this passage Grundtvig's insistence on the creation of Adam through the breathing in of the Spirit, and on the conjunction of flesh and Spirit in the incarnate life of the Son. Grundtvig goes on with a quotation from the prophet Ezekiel

»... will give you one heart, and give you a new spirit, and I will take away the stony heart out of your flesh; I will give you a heart of flesh so that you will walk in my way and keep my law and be my people, and I will be your God." When the Lord talks in this way and foretells the wonders he will do in the Church of Our Lord Jesus Christ, then at once we see that flesh here does not mean what is sinful, but what is soft and flexible, as opposed to what is hard and unfeeling, and so it means flesh as it was in the beginning, conjoined with spirit, and as it was in Christ Jesus ... And now we can well understand Jesus when he says and he will give his flesh for the life of the world, and that we shall eat his flesh and drink his blood, so as to live by him, as he lives by the Father, so as to be raised by him at the last day. Truly he speaks here of his true, real flesh and blood, but when he says that he gives his flesh for the life of the world, that is his pure unspotted body which was always the tool and temple of the Holy Spirit, and when he speaks of his flesh and blood which we shall eat and drink, that is his spiritual, transfigured body, with which he ascends on high, as he himself says »the words that I speak to you are Spirit and life; for this body was born of the Spirit and all that is born of the Spirit is Spirit.«

Therefore no-one shall tell us that we are fleshly and rely on the flesh, when we believe the Lord's words about the means of grace in his Church, and trust in their power; for what is given us there is both spiritual and bodily, like himself, in whom all the fullness of the Godhead dwells bodily. Our heart is by nature flesh, with faith and love it could become spiritual, but with sin it is ruined; but through baptism and communion, Jesus gives us his heart, so that a new man is born and grows, created according to God, in true righteousness and holiness. 
All our body is by nature flesh, and through sin it is made subject to death and corruption, but through baptism and communion it is renewed inwardly so as to be raised up again at the last day ${ }^{10}{ }^{10}$

In this sermon we see very clearly the consequences of this understanding of the interaction of flesh and spirit for Grundtvig's theology of the sacraments.

Let us now go on another ten years and see a little more in detail, what this conjunction of flesh and spirit will imply for the life of the Christian community, particularly for the life of the Christian community at prayer in the Eucharist. Here Grundtvig is preaching at Septuagesima 1834 and his text is taken from Psalm 104 (Wine which maketh glad the heart of man so that his countenance becomes joyful).

»Vine maketh glad the heart of man, so that his countenance becomes joyful. So says the Psalm, and although drinking songs say the same thing that does not mean that psalms must become drinking songs nor that drinking songs become psalms. It only shows that the Spirit who inspired the psalmist and all the prophets and apostles of the Lord, understands how to speak gracefully and how to choose images for himself and his divine activity where they are rightly to be found and where they are foreordained for this purpose from the beginning of the world...

»Although therefore we ought as Christians always to remember the apostles warning not to be drunk with wine wherein is excess, but to be full of the Spirit, so it is also true that at the Lord's table both bodily and spiritual realities are at work. It is true both in a bodily and a spiritual way, as the psalmist sings, that wine rejoices man's heart and bread strengthens it, because there the bread and wine are not just images of the Lord's body and blood, in which we share spiritually; rather they are incorporated and taken up into them, by 
his word which says Take this and eat it, drink ye all of this. Therefore, one of the early fathers rightly said, that the Lord in the eucharist took to himself the first creation and put the seal to his word that he had come not to destroy but to fulfil, just as he sent out his servants not to break down but to build up. The world, I suppose, can certainly not bear to hear this, for its conceptions of Spirit are so fine and empty that for even the least evident reality to be linked with the Spirit seems to the wise of the world something coarse or crass, as they say, something which not only weighs down and dishonours the Spirit but scares it off and drives it away. This however, only follows from the fact that the world, as the Lord says, in no way knows the Spirit of truth and cannot receive it, but is deceived and blinded by its own spirit, which is the spirit of the air, i.e. the spirit of delusion and deep emptiness. We Christians, however, who are baptised in the name of the Holy Spirit, that is to say plunged into and rooted in his divine personhood, as well as in that of the Father and the Son, should naturally only smile at the world's superstitious faith in a ghost under the name of Spirit. ${ }^{11}$

»Yes, my friends, what the Christians had for a time almost entirely forgotten, that they may now again see through the Spirit of the Father, who brings to our mind all that the Son has said, who so livingly reminds us of it, to God's glory and our own great gain, that we never forget it again, who so livingly reminds us that he who said, »what God has joined together, let no man put asunder «, he the perfect man, will never use his divine power so ill, as himself to do what he forbids. No, just as surely as the creator has brought soul and body together within our human nature, so will the saviour free both soul and body from the bonds of corruption... and just as humankind is created of the dust of the earth to be its king and to eat of its fruit and to live eternally, so the saviour will in no way abolish or derange this nature's order, but only loose the bonds in which nature has been placed on account of the sins of its king, that is to say of humankind. So, when by the world we understand the world which God created in six days by his Word, which he saw and found to be very good, then we shall also see that what the Lord says is joyfully and literally 
fulfilled, that God sent out his Son into the world, not to condemn the world but that the world through him might be saved. $\ll^{12}$

We have here an insistence that human flesh, which is made alive together with human spirit, through the creative and redemptive work of God the Holy Spirit is in total solidarity with the world, which is itself God's creation, and thus that the salvation, the transfiguration of the flesh of the believers, involves the salvation and transfiguration of the whole world. The water of baptism, the bread and wine on the Lord's Table, are fully part of the world of nature, but they become part of God's work in the redemption and transfiguration of the world. Similarly the images which the Spirit takes and uses in order to speak of the things of heaven are taken from among the things of earth, because from the beginning the things of earth were intended to convey a heavenly meaning, and to be open towards realities greater than themselves.

We also see here another instance of the importance which Grundtvig gives to John III: v. 16, and the way in which he sees this verse in the context of the gift of the Spirit to humankind and to all creation. God so loved the world that he gave his only begotten Son. It is in the Holy Spirit that the love of God is poured out into the world through the coming of his Son. It is in the Holy Spirit that the world is caught up into the eternal joy of God's kingdom which this love brings. Thus, this verse speaks of the transfiguring power of God which descends into humanity and through humanity into the whole creation and draws all creation up into the communion of the divine life.

So, in the great Pentecost sermon of 1838 , preached on this very text, Grundtvig concludes

»God so loved the world that he gave his only begotten Son; so that we shall not imagine that it would help if we had faith such as to move mountains, but had not love, the divine mother not only of all true virtues and all good deeds, but of all true joy and of eternal life, so that we shall never imagine that the all-powerful and divine love is something which can arise naturally of itself or can be created and brought into our hearts by some effort or skill of our own, but that it is God's gift of 
grace in Christ Jesus, a drop of dew from the Father's eye with eternal life in it, a gift of grace which he will grant to all those who believe in his only begotten Son, grant to all who believe, through the Holy Spirit in baptism, and will develop throughout the whole course of Christian life into an almighty power within us, which reveals his glory, and overcomes the world and death, so that we, like the apostles, do not hold our lives dear, for love challenges the last and most dangerous foe to fight, and praises the Lord in the fire, and thanks the Father in the moment of death, he who did not spare his only Son but made him to be a way out from death and a way into life for all who believe. ${ }^{13}$

Grundtvig here speaks in terms of martyrdom, a theme more common in him than we might think. The gift of the Spirit is the gift of a life which is stronger than death. And this we see in the deaths of those who give their lives for their love of God. This we see »with the strength of the martyrs in a trembling reed «.

But we also notice the baroque image of the drop of dew from the Father's eye which occurs in this passage, an image which might suggest H.A. Brorson rather than Grundtvig. The dew is a symbol of the morning, of the blessing of new creation, of light which triumphs over darkness, of love which triumphs over death. But here the drop of dew is also a tear. It is from the love of the Father, who in Grundtvig is always the centre of love in the Godhead, from the compassion of the Father which descends into the world creating from nothing in the beginning, redeeming in the victory of Christ in the midst of human history and at the end transfiguring all in the glory of the kingdom.

\section{VI - Postscript}

In this article we have looked at Grundtvig's attitude towards this question of the relation of spirit and body in the life of humanity, and the relation of the Creator Spirit to the life of creation as a whole, at different periods in Grundtvig's life, from the 1810s to the 1840 s and in different contexts, some discursive, some homiletic. Certain common themes have emerged and they have emerged in 
ways which suggest a deep affinity between Grundtvig's theology as a whole and that of the teachers of the early Christian centuries. As Niels Thomsen remarks in his admirable article in Tradition and Renewal, "What is astonishing is the naturalness with which Grundtvig constantly speaks out of a harmony with early Church faith and thought. Most powerful of all is perhaps where he sings and speaks out of a faith in the Trinity. ${ }^{14}$

One has a very similar impression re-reading some of the essays in For Sammenhangens Skyld and particularly that of Mortensen on the Holy Spirit. I find myself asking yet again how it can be that Grundtvig's approach to theology is so profoundly patristic, and in some respects so profoundly Eastern as it seems to be? I am reminded again of the way in which in a recent discussion, Christian Thodberg has spoken of $\gg$ the spontaneously patristic nature of Grundtvig's exegesis.«

How are we to account for this quality in Grundtvig's thought? This is a question which I pose, but do not pretend to answer. It is important for our understanding of Grundtvig himself; it is also important in the context of the dialogue between Lutheranism and Eastern Orthodoxy. In a more general way it can help us to see how Grundtvig could be a teacher for all Christians. In his unselfconscious way he seems able to speak out of the common faith and experience of the earliest centuries, to which all Christian confessions look back.

The influence on Grundtvig of Irenaeus in the eighteen twenties is of course evident and acknowledged, and the influence of Grundtvig's liturgical translations from Greek and Latin in the eighteen thirties is also widely recognized. But already before that it seems to me that there were other influences at work. Perhaps Grundtvig's first attraction to the poetry of the Anglo-Saxons was not only literal and historical, but also seriously theological. That is a line of thought which I believe deserves further exploration. But perhaps we need to look again at a Danish work which Grundtvig must have known as a student, and which, even if it did not excite him, may have influenced him in ways in which perhaps he was not fully aware. I refer to Frederik Münter's Haandbog i den Aldste Christelige Kirkes Dogmehistorie (1801 and 1804). Münter's work is not exactly exciting. He was too good a man of the eighteenth century with his instinctive revulsion from enthusiasm, mysticism and fantasy, to write an exciting study of the earliest Christian teachers. Perhaps also he 
was too much of a systematician to enter into their characteristic ways of seeing things. Having only recently come to recognize his possible influence on Grundtvig's understanding of Christian faith, I have not been able to look carefully enough at his work to feel confident in my judgement. But a first impression suggests that there are features in Grundtvig's theology, its pre-Nicene Trinitarianism, its emphasis on the doctrine of the divine image and likeness in humankind, its non-Augustinian attitude towards the fall, where memories of Münter's lectures may have been of real importance in forming Grundtvig's way of seeing things. Münter is certainly not in love with the writers of the second and third centuries, with Irenaeus, with Clement and Origen; but he treats them with respect. They are at least, in his eyes, much preferable to their successors. In particular he seems pleased when he is able to show that their anthropology is certainly not that of the later Augustine. In his work he gives us a general picture of the Christian faith as taught in the first centuries, which may at least have had some influence on the way in which Grundtvig's mind grew and which therefore might help us to understand »that fundamental agreement that existed between Grundtvig and the early Church, « to which Niels Thomsen points us.

Noter

1 A.M. Allchin, N.F.S. Grundtvig. An Introduction to his Life and Work.Aarhus 1997, p. 63.

2 N.F.S. Grundtvig, Varker $i$ Udvalg udg. v. G. Christensen og Hal Koch, København 1942, III, p. 430.

3 Ibid., p. 431.

4 Danne-Virke, 1817, II, pp. 39-40. I am deeply grateful to Dr Kim Arne Pedersen for his guidance in this part of Grundtvig's work.

5 Ibid., p. 159.

6 Danne-Virke, 1817, II, p. 164.

7 Danne-Virke, 1817, II, p. 174.

8 Ibid., p. 200. 
9 Chr. Thodberg (red.), N.F.S. Grundtvigs Pradikener, Kbh. 1942, p. 233.

10 Ibid., pp. 234-5.

11 Chr. Thodberg, N.F.S.Grundtvigs Pradikener, Kbh. 1984, p. 104.

12 Ibid. p. 105-106.

13 Chr. Thodberg, N.F.S. Grundtvigs Pradikener, Kbh. 1986, pp. 228-9.

14 A.M. Allchin et.al. (red.), Heritage and Prophecy. Grundtvig and the English Speaking World. Aarhus 1993, p. 198. 